GENDER STUDIES 20(1)/2021

\title{
sciendo
}

\subsection{8/genst-2022-0006}

\section{FEMALE AUTHORITY FIGURES IN DOROTHEA TANNING'S CHASM: A WEEKEND}

\author{
GABRIELA GLĂVAN \\ West University of Timişoara \\ gabriela.glavan@e-uvt.ro
}

\begin{abstract}
Little girls and young women are Dorothea Tanning's recurrent archetypes, defining and structuring her conceptual archive concerning gender and the feminine. A celebrated painter and sculptor who shaped her artistic vision in the proximity of the historical avant-gardes, Tanning was also a writer who revealed the mystery and estrangement of family ties in Chasm: A weekend, a novel she started writing in 1943 and published six decades later, in 2004. This singular book offers a privileged dialogue between literature and art, as several episodes revisit and translate the high tension of some of her most representative paintings. From within a feminist framework, the article will discuss aspects of female authority and control in Tanning's novel as dominant forms of female empowerment, present throughout her visual Surrealist oeuvre. I argue that examining these allegories reveals their role as connectors between the literary and the visual arts, between Dorothea Tanning's fiction and her painting. Keywords: Surrealism, woman artist, female sexuality, domination, violence.
\end{abstract}

\section{Introduction}

Dorothea Tanning's Surrealist art is a celebration of the female element affirming its extremes: precociousness in childhood, deviant adolescence, violent, irrational unpredictability, sexual freedom. The American artist shaped her creativity under the strong influence of the 1936 Fantastic Art, Dada, Surrealism exhibition at the Museum of Modern Art in New York. She briefly worked in commercial art, but once she met European artists seeking refuge from the war, she became acquainted with important names of the avantgarde, including Max Ernst. As Whitney Chadwick notes in her comprehensive volume Women Artists and the Surrealist Movement, "no artistic movement since the nineteenth century has celebrated the idea of woman and her creativity as passionately as did Surrealism during the 1920s and 1930s" (Chadwick, 1985, p. 290). However, Surrealist male artists often acted brutally in relation to women and, essentially, the feminine. As a result, some 
female artists ceased to identify as part of the movement. Others established their own ground inside the Surrealist paradigm and "turned instead to their own reality" (Chadwick, 1985, p. 292). Female artists such as Leonora Carrington, Leonor Fini, Kay Sage, Remedios Varo, Frida Kahlo and Dorothea Tanning are relevant examples of the way in which gender negotiations influenced the history of the avant-garde.

Although primarily recognized as an artist whose career spanned almost a century, Dorothea Tanning is also critically acknowledged as a writer, for her poetry and her only novel, Chasm: A Weekend (2004). Tanning started to write it in 1943, and it was first published in Zero magazine in 1949; almost two decades later, in 1977, it was re-published under the title Abyss, and then, in a revised and final form in 2004 as Chasm: A Weekend. A spectacle of female power and a surrealist parade of unusual characters, Tanning's novel is a poetic fairytale about a magical child redefining her destiny.

My aim in analyzing this novel is to discuss Tanning's fictional articulation of female authority, autonomy and domination (sexual and otherwise) in the context of a fertile intersection between art and literature. I will rely on a conceptual framework that defines these terms in the proximity of feminist theory, semiotics, and cultural history, and I will use the term authority with the straightforward meaning of power to command or influence others' behavior. These terms, however, are immensely complex. Authority and the lack of it, having a voice and access to language, women's empowerment and self-representation have been the focus of seminal critiques by authors such as Carol Gilligan, Teresa de Lauretis and Sally Robinson, among others. The historical materiality of the female experience translates into discourses that reclaim the necessity of a female voice, reflecting a political body and its revised significance.

In order to explore instances of female authority in Chasm, I will focus on the protagonist, a seven year-old girl named Destina and her murderous governess Nelly, as they make a volatile tandem united by their common history of loss, since they are both orphans. This uncanny alliance works like a diabolical unit, the two girls empowering one another to cross boundaries and subvert the order of everyday bourgeois life. Nelly is, in many ways, an older, more incisive version of Destina. The dynamics of these characters is highlighted by other female participants in the narrative, such as Destina's great-grandmother, the Baroness, or Nadine Coussay, a guest at Meridian's house and his latest erotic obsession (her name is a clear allusion to André Breton's 1928 novel, Nadja). Tanning presents a triad of women encompassing three distinctive ages - childhood, youth and old age - allegorized 
as three figures that seek empowerment and control over their fate and those who pose a threat to it.

I argue that two main categories of authority can be identified in Tanning's specific dialect in Chasm: a paradoxically domestic/savage one, representing Destina's rule over the house and the desert and her friendship with the mountain lion; the baroness can be identified as domestic authority, given that Windcote belongs to her family. The second one is erotic authority and it refers to Destina's apparently chaste seduction of Albert Exodus, and to Nelly's complicity in Meridian's sadomasochistic sex games. Although they have all been allegorized in Tanning's visual work, these aspects develop more consistently in her narrative prose. I will invoke arguments from the artist's vast range of representations of the feminine in Surrealist terms, as convulsive beauty and radical affirmation of female agency. This article will consider the unifying vision in which Tanning integrates her vast gallery of autonomous, self-contained, mysterious and intangible female characters, establishing her own version of the Surrealist revolutionary project. Their authority derives from their empowerment as bearers of meaning separate and independent from the opposite sex. Tanning's male/female dichotomy is clear-cut: women want to rule, seize power, reclaim their property, body and voice; men are subverted by their insatiable perverted desire, yearning to be dominated, both sexually and mentally. The form of female authority imagined in Chasm is a fluid continuation of the positions of power her female characters display in many of Tanning's paintings. However, the artist carefully avoided to be directly associated with feminism, for fear of an unnatural separation from her male peers (Tanning, as cited in Chadwick, 1985, p. 12). Her work, though, is clearly oriented towards problematizing the feminine and its representations in art and literature. This overlapping of artistic dialects amplifies the depth of the surreal territory on which Tanning articulated her vision of female authority and empowerment.

Female power has been theorized in various contexts by feminist critics, and Mary Beard's approach stands out as particularly significant. In her exploration of female power in classical literature, she argues that an important dimension of women's disempowerment is located in discourse, which reaches audiences primarily through the speaker's tone of voice. Biologically endowed with a higher-pitched voice, women are often silenced or disregarded due to a historically constant belief that higher tonalities are unpleasant and often disturbing. Arguing that this belief has been perpetuated as a prejudice, an assumed truth rather than a fact, Beard (2017) postulates that "we need to go back to some first principles about the nature of spoken authority, about what constitutes it, and how we have learned to 


\section{GENDER STUDIES 20(1)/2021}

hear authority where we do" (p. 58). Discourse in literature functions differently, though, lacking the added value of the spoken word. Tanning seems to have been aware of this detail, therefore Destina's precocious empowerment through discourse is evident in her encounter with Albert, in her nursery, when she shows him her secret trophies. Tanning contradicts the premise of Beard's observation, as her protagonist is not yet a woman, but a little girl learning adult manners and strategies. She is rather a fantastical character, unaffected by the norms of gendered discursive authority. Once again, Tanning's choice to place a little girl in a leading role challenges the notion of femininity and female power by subverting the idea of a definitive and complete, mature identity. This reminds us of Julia Kristeva's theorizing of adolescence in The Adolescent Novel where she tackles the notion as part of a psychoanalytic framework. She clarifies that "with 'adolescent' I mean less a developmental stage than an open psychic structure" (Kristeva, 1995, p. 136). The term "open structure" is borrowed here from biology, and, in Kristeva's critical vocabulary, it is "a living organism whose sole purpose is to renew itself by opening itself up to its environment or other structures" (ibid.). Adolescence and its promises are central allegories that connect Tanning's fictional dialect to her painterly one.

As a term of critical theory, empowerment is a process whereby women come to believe in their ability "to construct, and take responsibility for [their] gendered identity, [their] politics and [their] choices" (Alcoff, as cited in Rowland-Serdar, 1984, p. 432). Although applied to a literary text, the notion of female empowerment I use is essentially rooted in this definition.

\section{Sadeian issues}

One of the most relevant instances of female authority appears in Chasm is the sadomasochistic relationship between Nelly and Meridian. In this affair, the roles are reversed, as the master becomes the erotic slave, and the apparently insignificant Nelly takes charge as a ferocious dominatrix. Sadism is, for Tanning's female character, a form of empowerment, as sexual power is the main dimension of female ascendancy in Tanning's novel, and the novel is an extravagant example of the aesthetization of erotic violence. As Gaby Wood noted, Chasm is "a magical Sadean nursery rhyme" (Wood, 2004, p. 7), and it directly favors a reading through the lens of the famous French aristocrat who revolutionized literary eroticism by shifting the attention to female sexuality as a separate realm of human existence, divorced from the necessity of reproduction. Feminist author Angela Carter 


\section{GENDER STUDIES 20(1)/2021}

explores the writings of Donatien Alphonse François de Sade (the Marquis de Sade, 17401814) in her long and complex essay The Sadeian Woman: An Exercise in Cultural History (1979). A radical revision of the cultural determinism of gender roles and a critical exploration of sexuality and pornography, Carter's rereading of Sade signals a significant effort to identify some turning points in Western culture when traditional paradigms were overturned and new attitudes and concepts emerged. A feminist of the third wave, Angela Carter interprets Sade as a revolutionary writer demolishing a static mythology of the body and sexuality. She states that: "Sade remains a monstrous and daunting cultural edifice yet I would like to think that he put pornography in the service of women, or, perhaps, allowed it to be invaded by an ideology not inimical to women" (Carter, 1979, p. 42). Catriona McAra (2013) states that "Carter reciprocally put Sade at the service of feminism, and that practitioners like Tanning are themselves evocations of the liberating Sadeian woman that Carter discusses" (p. 72). Carter draws in her approach to sadism on Michel Foucault, who questions the phenomenon both historically and as a cultural fact. The concept, Foucault believes, is "not a name given to a practice as old as Eros; it is a massive cultural fact which appeared precisely at the end of the eighteenth century, and which constitutes one of the greatest conversions of Western imagination: unreason transformed into delirium of the heart" (Foucault, 1965, p. 97). Carter's Sadeian feminism is based on the observation that Sade empowered women by presenting them in positions of erotic control and domination, contrary to normative pornography, describing women as subservient, powerless and permanently enslaved by male desire. Carter (1979) articulates her hypothesis about Sade in clear terms:

He was unusual in his period for claiming rights of free sexuality for women, and in installing women as beings of power in his imaginary worlds. This sets him apart from all other pornographers at all times and most other writers of his period. (p.36)

The convergence between Surrealism and Sadism is present in Dorothea Tanning's novel and is facilitated by their common aesthetic predilection for violence. As André Breton proclaimed in the first Manifesto of Surrealism, "Sade is Surrealist in Sadism". The Marquis was revered by surrealists as a prophet and clairvoyant. Later, in 1934, Breton wrote a poem dedicated to Sade in his volume L'air de l'eau: "The Marquis de Sade went back inside the spewing volcano/From which he came/With his beautiful hands still fringed/His eyes like a young lady's/And that reason at panic level that was/His alone/But from the phosphorescent 


\section{GENDER STUDIES 20(1)/2021}

drawing room with viscera lamps/He never ceased shouting mysterious orders/Which open a breach in the moral night (Breton, as cited in Black, 2013, p. 2). Similarly, in his volume of eight poems, entitled Paramyths, Max Ernst eulogizes Sade enthusiastically: "The divine marquis,/the emblem of pride,/the burning iceberg,/bird o paradise...(Ernst, as cited in Black, p. 2).

Tanning, well aware of the Surrealists' fascination with Sade, assimilated Sadeian elements both overtly, as she did in Chasm, and ironically, as in the painting Le Petit Marquis (The Little Marquis, 1947), where the aristocratic libertine appears dwarf-like, yet carefully dressed like an eighteenth century nobleman with a whip in his hand, cracking it as it penetrates a canvas representing four human figures. He seems half immersed in dark waters as the fall of his whip goes high into the air, like a magical serpent. The suggestion that the Marquis is little could be understood as an allusion to childhood as the age of the irrational and of freedom.

Nelly's sadomasochistic relationship with Meridian represents the culmination of his depravity and her form of relief from the limitations of her role as house help. The wealthy master of Windcote gained his fortune from selling sex toys, yet his moral transgression is not the root of a liberating philosophy, as debauchery was in Sade's case. His abusive relationship with his daughter's governess is a power game quickly overturned one day. Infatuated with Nadine, Meridian whispers her name in his sleep, and Nelly hears him. Tied to his bed by the dominatrix, Meridian proposes role-play, with Nelly as Nadine. Humiliated, she turns away for a few moments, only to find him asleep upon returning. That is when, on an impulse, she decides to end the game in murder:

She came back to the bed and stood over Meridian. Looking down at his twisting and slavering, hearing his whining of the odious name, it seemed to her that he no longer had an identity at all. [...] She studied the mucid cavern of his mouth, as it opened to swallow the world, this purple grotto emitting sound. And the hole in his belly - it was only a navel but it too was whispering [...]. Longing for quiet, she drew out from her skirts the ice pick, and grasping it with both hands brought it down at the center of his big neck, and as soon pulled it out, releasing a tiny red jet like a toy fountain. The face on the pillow contorted, a gagged cry, more like a growl, held the mouth open while a violent reflexive spasm nearly tore him from his bonds. (Tanning, 2004, p. 111)

Meridian's death while practicing sadomasochism validates his exclusion from the inferno of sexual gratification through physical pain. His grotesque desire is ultimately fulfilled through the dark fantasy of being dominated and hurt, a reversal meant to punish 


\section{GENDER STUDIES 20(1)/2021}

him for his failed roles as a father, master, and lover. Tanning's radical position towards Sade validates her original reloading of his central allegories - her choice to end the erotic game in violent murder proves the artist's willingness to translate the French author into her own dialect.

\section{The trouble with Destina Meridian}

Possibly her most expressive work in terms of reading Chasm as a complex feminine mythology is a self-portrait of Dorothea Tanning entitled Birthday. It is the painting that impressed Max Ernst in 1943, as he was trying to gather 31 of the most relevant women artists of the moment for an exhibition organized by his then wife, Penny Guggenheim, at her Art of this Century private gallery. The painting foregrounds a female presence, the artist herself, standing, as if for a brief moment, on the corridor of a vast interior, in front of an endless reflection of doors, a perfect illustration of the mise-en-abyme. Her dignified stance, with her hands slightly lifted, as if to welcome rather coldly an intruder violating her privacy, contradicts the lack of formality in her attire. Half-nude, with breasts exposed, wearing a baroque blouse while barefoot, the artist's avatar is the master of a mysterious domain. A griffin sits at her feet, with open wings, ready for flight. Strange branches, like governess Nelly's contorted junipers in Chasm, adorn her skirt, petrified snakes of an invisible Medusa. This portrait of the young artist, bravely looking spectators in the eye, disheveled yet aristocratic, guarded by her magical animal, translates into her literature as the supernatural friendship between the knowledgeable seven-year-old Destina Meridian and a mountain lion. Tanning's little and young girls, ever present in her paintings of the 1940s and ' 50 s, are creatures that seem to have quickly grown out of childhood, maintaining the deceitful looks of innocence, while manipulating adults as they please and orchestrating devious strategies of revenge and punishment.

Christine Battersby proposes a feminist interpretation of the position of the female artist in another representative painting for Chasm, Self Portrait (1944): "Tanning draws attention to herself as embodied and also as dependent, involving a kind of active passivity that seems intimately bound up with sense of herself as an artist who is always and forever embodied. Tanning's image evokes a series of contrasts: activity/passivity; nature/culture; freedom/dependence; dream/reality; subject/object; immanence/transcendence" (Battersby, 2007, p. 147). This painting essentializes Tanning's experience of living in Sedona, an outpost in the Arizona desert. She and her husband Max Ernst moved to Sedona in 1946, but 


\section{GENDER STUDIES 20(1)/2021}

their first contact with the place dates back to 1943. Surrounded by the majestic canyon, enduring the scorching heat of burning rock and sand, the artist seems to emerge at one point from the shelter of her house to face the aggressive nature around her in a direct confrontation. Delicate and exposed, the feminine silhouette is projected against the raw landscape of incandescent red rock, tamed by frigid hues of blue and green suggesting evaporated water and a greater density of the air. For Tanning, the primal archetype of her oeuvre is herself as an artist, confronting the unreal landscape of her inner worlds. Catriona McAra (2017) argues that "Self-Portrait becomes a raw setting for Abyss/Chasm - an active visual parallel rather than passive illustration" (p.46). The explosive drama of Chasm takes place at Windcote, the extravagant desert manor of Raoul Meridian, Destina's father figure and adoptive only parent. The terrifying and magnificent landscape of the desert and the canyon hyperbolizes the essential conflicts of the novel, generating a hallucinatory atmosphere and a growing sense of universal terror. Tanning declared of her living in Sedona that, at least artistically, it was an overwhelming experience: "Then as now the decibels of nature can crush an artist's brain ... So I lock the door and paint interiors. Great events... Chilly, secretive paintings that typify my response to the diabolical landscape outside" (Tanning, 1986, p. 82).

The suffocating sensation of being imprisoned inside defines one of Tanning's bestknown paintings, Eine Kleine Nachtmusik (1943). The specters of the desert infiltrate the deceitful serenity of the house, and the composition is also suggestive of the dark, restless mysteries unfolding behind closed doors in uncanny houses. Floating like sleepwalkers across a massive hallway, two young girls seem to have fought a gigantic sunflower that fell down wounded near the staircase. Here, the female action is hyperbolized, closing on violence and excess. The indication of conflict and physical fight displaces the characters from their apparent captive state and elevates them to a position of power. The earth colors of the composition are violently contradicted by the red background of the long carpet, inflamed in its turn by the bright yellow of the sunflower, suggesting a reflection of the cosmic union that binds together red stone and golden sunlight. The artist commented on this painting in the last year of her life:

It's [the picture] about confrontation. Everyone believes he/she is his/her drama. While they don't always have giant sunflowers (most aggressive of flowers) to contend with, there are always stairways, hallways, even very private theatres where the suffocations and the finalities are being 


\section{GENDER STUDIES 20(1)/2021}

played out, the blood red carpet or cruel yellows, the attacker, the delighted victim. (Tanning, as cited in Carruthers, 2011, p. 146)

Eine Kleine Nachtmusik echoes Tanning's major themes in Chasm: the labyrinthine house, young girls participating in unusual, mysterious rituals, suggested (as opposed to overt) erotic violence, the involvement of natural elements as background for strange acts.

Interior with Sudden Joy (1951) is another work that seems to orbit around Chasm, reinterpreting its allegories of feminine power. It alludes to monstrosity and early loss of innocence, present in the novel as unstoppable corruption and sudden sexual maturation. Here two young girls seem to be caught in the middle of a nocturnal party in a classroom, possibly at a boarding school, as another woman emerges from the shadows, carrying a lamp. Drawing from Freud and psychoanalysis, as many Surrealists did, Tanning seems to agree that sexuality is a social and cultural construct that has to be critiqued like any other fundamental aspect of human life. The two girls on the cusp of adolescence, dressed in undergarments and provocative lingerie, wearing make-up and elegant heels, rebel against the rules of the boarding school by partying and smoking. Verses of the damned poet Arthur Rimbaud are written on the blackboard, while a gigantic supernatural creature with strange breasts and numerous legs dances along with them. A magical animal is present, too - a massive dog, petted on the head by one of the girls. Katherine Conley believes it is the weather that awakens sexual desire in these girls: "out of the physical heat of the Arizona desert Tanning develops sexual heat manifested as forceful energy emanating from young girls" (Conley, 2013, p. 125). An important tool of female empowerment, control over one's body and sexuality is a continuous thematic line that structures an overarching connector between Tanning's work as a writer and her artistic vision.

Children's Games (1942) glorifies children's inclination to disobedience, a topic that plays a central role in Chasm. The painting seems to materialize Tanning's observation about the static, monotonous atmosphere of her bourgeois childhood home: "nothing happens but the wallpaper" (Tanning, 2001, p. 16). Two girls tear off wallpaper, exposing hidden, potentially forbidden images. Tanning's interest in breaking taboos prevails in this painting, and the exciting act makes the girls' hair swirl upright, as if attracted by an invisible magnet. Katherine Conley sees a gender issue in this act of revolt: "The way these children attack wallpaper serves as a challenge to the conventions society imposes on their bodies, particularly the convention that assumes a correlation between a tidy house and a pure, inviolate feminine body" (Conley, 2013, p. 125). Games of power, Destina's mysterious 


\section{GENDER STUDIES 20(1)/2021}

games of seduction, Meridian's strange sex games and the fantastic game structured by setting (Windcote, the desert), characters (Destina and the mountain lion) and plot (an orphan seeking to reclaim her position in the family genealogy and her rightful inheritance) make up the thematic and symbolic structure of Chasm. These echoing elements reiterate the interconnectedness between the different forms of art practiced by the author.

Palaestra (1947) presents a high tower of children bodies, an allusion to the metamorphoses of growing up. It could also be connected with the introductory chapter of Chasm, where a long line of Destinas leads to the enigmatic little girl who gradually took charge of the small domestic universe of Windcote. She has been compared to Lewis Carroll's Alice, and her anomalous precocity makes her "an Alice with foresight" (McAra, 2011, p. 19). Her austere room suggests a premature entrance into adulthood: "there was nowhere anything to suggest that this was the home of a child: no dolls, no toys, no diminutive furniture of the sort that generally delights the heart of a little girl" (Tanning, 2004, p. 55). As an Alice-figure, Destina seduces Albert Exodus one of her father's guests. Her territory is just as wide as the mountain lion's, as she can master, at the same time, "the secretive world of the nursery as well as the vast and magical desert surrounding the house" (Carruthers, 2011, p. 140). The "dollhouse architecture" (Mahon, 2007, p. 153) of Destina's room is another argument supporting the connection with Lewis Carroll's Alice in Wonderland.

Not only as the daughter of a mad millionaire but as a precocious child, too, Destina refused to be obedient and submissive to all the adults around her. On the contrary, she uses every opportunity to prove her insubordination: "Destina easily triumphed over her governess in almost every clash of will [...] moreover, the closeness and monotony of their days together had resulted in a graceless familiarity that belied the relationship of governess and pupil, making it easy for the girl to have her way" (Tanning, 2004, p. 88). Her friendship with a dangerous predator is the definitive proof of her ability to master not only humans, but wild beasts as well. In a psychoanalytical reading, the meaning of this uncanny alliance can be understood in terms of subconscious representations: "the lion could easily be said to represent Raoul Meridian's repressed guilt [...] As the dominant male, the presence of a lion would usurp Raoul's patriarchal authority. The lion also represents nocturnal dreaming, insatiable desires and, ultimately, the death drive" (McAra, 2017, p. 88).

Deeply infused with Gothic elements projected onto a Surrealist background, Chasm abounds in direct allusions to the major Gothic literature that placed women in the middle of all action, transforming them into its main archetype. Consequently, the term can be 
brought into this analysis - Gothic sensibility and its premodern representation of female power stylized Tanning's surrealist vision into a composite, innovative vision of authority and control. Feminist readings of the Gothic have become part its critical canon, and reading Tanning through Robert Miles' concepts signals an important aspect of the female Gothic, namely its preference for a scenario "based on a daughter's search for an absent mother (Miles, 1995, p. 45). Moreover, the artist herself confirmed her interest in the aesthetics of the Gothic. In an unpublished interview Tanning gave Victoria Carruthers in 2009, she stressed that "Gothic fantasy was very influential in my life. It allowed the possibility of creating a new reality, one not dependent on bourgeois values but a way of showing what was actually happening under the tedium of daily life. Of course, I was always thrilled by terror and chaos also" (Carruthers, 2009). Destina's search for the maternal element signals the fundamental crisis scenario the child character proposes - as Nancy Chodorow theorizes in her influential The Reproduction of Mothering. Psychoanalysis and the Sociology of Gender (1978), “women's mothering is of profound importance[...] for ideology about women" (p. 3). From this perspective, motherhood is a transformative experience that renegotiates women's social and political relationships, and Tanning's choice to present it as problematic signals her interest in bringing it into a critical spotlight. The absent mother is more than a fairytale trope; it is a figure that reminds of Tanning's anti-canonical representation of Western painting's essential Madonna with child in her Maternity painting (1947) - a weary maternal figure in rags carries her baby through an arid, lonely desert, with dark clouds above her head, as a reminder of the unspoken challenges of maternity.

Tanning proposes a system of surrogate maternal figures, strengthening the connection between the scriptural and the visual. The Baroness, Destina's greatgrandmother, is a Destina herself. Nelly, the governess and the mountain lion, her friend, are also figures that replace the maternal element. However, The Baroness is the real maternal authority at Windcote, although an unrecognized one. Wearing a hat and hiding her identity from her great-granddaughter, the Baroness participates in Meridian's extravagant dinner party, where many notable guests are invited. Indirectly, as he wonders about the Baroness' origins and past, he offers a glimpse into the life of the mysterious matriarch:

an unadorned woman - Meridian called her simply 'the baroness'- sat alone by the piano as if she had been left there long ago like a piece of undusted furniture, ignored and ignoring, her face weathered to the hue of bronze leather with a fine network of wrinkles, Old? But how old? (Tanning, 2004, p. 66). 
The intricate family tree of the many Destinas that has led to the latest Destina, the protagonist of Chasm, operates a system of Russian dolls (McAra, 2017, p. 75), one containing many others, while at the same time apparently generating new entities that keep the essential nominal dimension of their forebears. With her easily decipherable symbolic name, Destina Meridian is a child of destiny, of blind fate hiding in unusual choices and bold decisions. Since the first Destina, a young woman of Portsmouth, married Tray Thomas, a sailorman, the presence of a "meridian" on the imaginary map of this lineage adds a spatial dimension (McAra, 2017, p. 76) to the historical presence of this irreverent matriarchy. Moreover, I want to stress the longitudinal factor implied by the notion, as movement, travel and, ultimately, flight from the scourge of war define the family narrative. McAra (2017) makes the important observation that it is the female name that transcends generations, not the male family name: "Unlike traditional family trees which chart the surname of the male from generation to generation, in Tanning's story it is the female which is privileged, thus constructing what could be read as a very feminist narrative" (p. 74). Consequently, "the genealogical prelude", where the reader discovers the story of many generations of women having the same name, "re-presents a feminist historiography" (ibid.).

Destina and her governess form a strange, unlikely tandem, emphasized in the novel's opening scene. Their connection comes from their respective relationships with the apparent master of the house, Raoul Meridian: Destina is his adoptive daughter, while Nelly is his occasional mistress. Both collect unusual objects that can easily be considered fetishes - Destina seems to be gifted eyes and animal body parts by a magical beast wandering the desert and canyon, while Nelly gathers juniper wood and nougat. Lonely and delusional, the governess fantasizes about having a baby with Meridian - "she passes her hand over her naked stomach in a dreamy circular movement" (Tanning, 2004, p. 15) - with the clear intention of replacing Destina with a biological child that would be the rightful heir of Meridian's fortune and the true master of Windcote. Nelly violently transgresses the dominant role Meridian gave her in bed, becoming, at least in her view, a figure of authority and power. This dangerous fantasy is encouraged by her apparent authority over Destina, although the little girl's fierce independence denies Nelly this satisfaction. In turn, Nelly sought privacy and self-reliance from her first days at Windcote:

When she came to Windcote it was assumed that she would share the comfortable apartments of her little charge, the daughter of the house. She refused. Oh no. Give her a room of her own, a private 


\section{GENDER STUDIES 20(1)/2021}

room no matter how small or humble. And as she was not really a servant but had come as companion and governess, her request was granted. (Tanning, 2004, p. 15)

The logic of the fairy tale is obviously present at this point in the narrative, as the servant's obscure desire for power threatens the fragile balance of forces in the bizarre manor. The house is an important third party accompanying the governess-pupil tandem, an implicitly feminine space of protection. Tanning dismantles this classical metaphor of space, as she had done in many of her paintings of the 1940s and 1950s. Houses and interiors are not spaces of protection, and enclosure does not imply familiarity, warmth, communication. These are, on the contrary, haunted territories, caverns and, unavoidably, chasms that, instead of hiding and protecting, expose and betray. As Katherine Conley (2009) observes, “Tanning's paintings redefine domestic space for young women as claustrophobic, haunted by malevolent spirits" (p.50). Haunted domestic interiors are a recurrent trope in Tanning's work. Besides familial spaces, Tanning was fascinated by the uncertain nature of hotel rooms, as they are transitory living spaces where anonymity and intimacy collide. This artistic vision is materialized in one of Tanning's most spectacular works, the diorama Hôtel du Pavot, Chambre 202 (Poppy Hotel, Room 202), where soft sculptures, shaped like ghosts, emerge from the walls and furniture of a hotel room. For Tanning, space becomes the revelator of the inner worlds of those who inhabit it, therefore Windcote, much like the domestic interior of Birthday, is the home of an unusual mistress. The first chapter opens with an essential statement: "Few travelers ever see the buildings of Windcote" (Tanning, 2004, p. 13). Hidden in plain sight, the vast building dominates the desert and seems to emerge suddenly out of thin air, as if through a magic trick: “...for several miles of punishing washboard road there is still nothing but dust and cactus. Then, abruptly, the house is there, as shocking as a fallen meteor. Ponderous, tall, defiant and truly alien, it nicks the desert like a weapon" (ibid.). This symbolic act of violence announces the atrocious murder of Raoul Meridian, during a fatal erotic encounter with Nelly, when she kills him with an ice pick. Although feminized, reflecting the paradoxes and idiosyncrasies of its owners and inhabitants, Windcote is, first and foremost, the result of an absurd game pushed to the limit, the creation of a delirious mind: "Sure Windcote, its very name a masquerade, can only have sprung full-blown from some conjurer's chant” (Tanning, 2004, p. 14).

The father-daughter competition for the ownership of the manor and for authority on its premises develops like a cold war between two apparently unequal forces. From very early in the timeline of the narrative, Meridian's lack of authority over his very young 


\section{GENDER STUDIES 20(1)/2021}

daughter becomes obvious. As she playfully asks him if she really had to leave the living room, as Nelly ordered, he seems incapable of taking on his parental role and tell the child what to do:

Turning her face toward the far left corner of the room, the child smiles again, "Do I have to, Papa?" she inquires nicely.[...] Presently an indolent man's voice replies.

“Why, yes, I suppose so. Yes, of course," and he laughs quietly. (Tanning, 2004, p. 18)

Lacking the skills to communicate with his precocious adoptee, Meridian remains unaware of the little girl's adventures in the desert, as he seems equally obtuse in anticipating Nelly's murderous intentions. Once Meridian is dead, Destina reunites with her greatgrandmother, the baroness, and they become the rightful owners of the manor. Tanning's notion of female authority is finally complete. The author enables the elder woman to tell the girl the story of her mother and her grandmother, both fatally caught in Meridian's poisonous trap, as he had proposed marriage to both of them, since they illicitly became pregnant and had no choice but to accept.

Like a prologue to the novel itself, the introductory Destina descending is a genealogy of the protagonist, enlisting a long line of Destinas, the little girl's ancestors. Their stories could be read as a unitary narrative suggesting a descent from a state of grace into the fallen condition of a human destiny. The latest Destina came into existence due to the rebellion, insubordination and sense of independence of her female forebears, as if they had poured their eccentricities and heresies into one final version of their own imperfect fate. Destina's genealogy comprises 283 years, from 1682 to 1965, and this complex family tree stands out solely because of its irreverent women. For almost three centuries, one Destina followed another, apparently reloading the same destiny, as if seeking to perfect it.

In one of Chasm's opening scenes, Destina defies the orders of her governess after she is found to be hiding in the dining room, where Meridian and his guests were going to have dinner later. Her extraordinary presence is marked by an element accompanying supernatural beings, angels, saints, fairies - an aura of faint light, so that she beams in the dark like phosphorus. Catriona McAra interpreted this detail as a point of convergence between Tanning's novel, written under the influence of her staying in Sedona, the remote outpost in the Arizona desert, and Western film. This "distinctive and recurring white light" (McAra, 2019, p.86) is the element that connects the artist's Surrealist vision with the Hollywood tradition of the Western film, where spotlighting was used to emphasize the 


\section{GENDER STUDIES 20(1)/2021}

beauty of female characters. McAra interprets this element as an instrument of empowerment in Tanning's Chasm, used to highlight the otherworldly nature of the dangerous femme-enfant collecting animal body parts and receiving eyes as souvenirs from a mountain lion. Destina makes a memorable entrance, as she sits, stiff and motionless, at the table where adults used to eat. Her gracious poise, her strict body language and minimal gestures suggest knowledge beyond her years. Her glow makes her appear spectral and, in retrospect, threatening and dramatic like a vengeful angel: "Her pale skin and white dress lit up the beating dimness like phosphorus...[...] [Nelly] sees the little girl sitting in her aura of whiteness" (Tanning, 2004, p. 17).

\section{Conclusions}

Dorothea Tanning's most relevant themes emerged in the period when she visited Sedona. That is where she and Max Ernst moved in 1946. The arid landscape and the proximity of the desert seem to have influenced her art and literature significantly. Under these circumstances, Tanning demolishes the false edifices of bourgeois adherence to anachronistic values and cultural practices that preceded modern attitudes towards the feminine and its guises and shapes. Her version of female empowerment in Surrealist literature is fundamentally character-driven. In Chasm, authority and power are represented with the same instruments the artist used for painting: raw emotions, explosive violence, and sexual freedom. Tanning's oeuvre as a painter contains, in artistic disguise, all the major female-related themes of Chasm. Authority and empowerment are conditioned and affirmed as strategies of (re)gaining control over a life story confiscated by an abusive master. Destina Meridian seems to be endlessly replicated in Tanning's paintings and in the particular mythology she created out of a preexisting collective fascination with the uncertainty of childhood and adolescence. By choosing allegory as the preferred tool of translation between fiction and painting, the American surrealist artist ensures that the narrative remains at the core of her imagination.

Although not a declared feminist, Tanning reconstructed, in her art and in her literature, an avatar of the modern woman that desires power in order to reshape her biographical history and gain control over its direction. Apart from exerting their erotic power and seductive virtuosity, Tanning's female characters impose a political code that establishes a flexible hierarchy of power roles in the unusual setting of Windcote, in the Sedona desert. 


\section{GENDER STUDIES 20(1)/2021}

\section{References}

Battersby C. (2007). The Sublime, Terror and Human Difference. Routledge.

Beard, M. (2017). Women and Power. Profile Books.

Black, C. (2013). Sadism and Surrealism. The Marquis de Sade and the Surrealists. Elektron Ebooks.

Carruthers, V. (2011). Dorothea Tanning and Her Gothic Imagination. Journal of Surrealism and the Americas 5(1-2), 134-158.

Carter, A. (1979). The Sadeian Woman. Virago.

Chadwick, W. (1985). Women Artists and the Surrealist Movement. Thames and Hudson.

Chodorow, N. (1978). The Reproduction of Mothering. Psychoanalysis and the Sociology of Gender. University of California Press.

Conley, K. (2009). Safe as Houses: Anamorphic Bodies in Ordinary Spaces: Miller, Varo, Tanning, Woodman. In P. Allmer (Ed.), Angels of Anarchy, Women Artists and Surrealism (pp.46-53). Prestel.

Conley, K. (2013). Surrealist Ghostliness. University of Nebraska Press.

Foucault, M. (1965). Madness and Civilization: A History of Insanity in the Age of Reason. (Richard Howard, Trans.). Tavistock.

Kristeva, J. (1995). The Adolescent Novel. In J. Fletcher \& A. Benjamin (Eds.), Abjection, Melancholia and Love: The Work of Julia Kristeva (pp.8-23). Routledge.

Mahon, A. (2007). Eroticism and Art. Oxford University Press.

McAra, C. (2011). (Re-)reading (Post-)Surrealism Through Dorothea Tanning's Chasm: The Femme-enfant Tears Through the Text. In A. Kérchy (Ed.), Postmodern Reinterpretations of Fairy Tales: How Applying New Methods Generates New Meanings (pp. 421-442). The Edwin Mellen Press.

McAra, C. (2011). "Blind Date”: Tanning's Surrealist Anti-Tale. In C. McAra \& D. Calvin (Eds.), Anti-Tales: The Uses of Disenchantment (pp. 100-114). Cambridge Scholars.

McAra, C. (2011). Surrealism's Curiosity: Lewis Carroll and the Femme-Enfant. Papers of Surrealism, 9, 125 .

McAra, C. (2013). Sadeian Women: Erotic Violence in the Surrealist Spectacle. In G. Matthews \& S. Goodman (Eds.), Violence and the Limits of Representation (pp. 69-89). Palgrave Macmillan.

McAra, C. (2019). Glowing Like Phosphorus: Dorothea Tanning and the Sedona Western. Journal of Surrealism and the Americas, 10, (1), 84-105.

Miles, R. (1995). Ann Radcliffe: The Great Enchantress. Manchester University Press.

Tanning, D. (1986). Birthday. Lapis Press.

Tanning, D. (2001). Between Lives: an Artist and her World. W.W.Norton \&Co.

Tanning, D. (2004). Chasm: A Weekend. Virago Press.

Wood, Gaby. 2004. "I've always been perverse”. Interview with Dorothea Tanning. The Observer, 7. Retrieved from http://www.theguardian.com/artanddesign/2004/aug/15/art.fiction [Accessedd 2020, July 10].

Rowland-Serdar, B. \& Schwartz-Shea, P. Empowering Women: Self, Autonomy, and Responsibility. The Western Political Quarterly, 44(3), 605-624. 
Gabriela GLĂVAN is an Associate Professor at The West University in Timișoara, The Faculty of Letters, History and Theology where she teaches Comparative Literature. She is the author of a book on Romanian modernism (2014), of a critical essay on Franz Kafka's short stories (2017) and on Max Blecher \{read: /'blekər/\} (2020). She has published numerous academic studies on modernism, the avant-garde, and post-communism, and is a contributor to several cultural magazines. 